craniofacial ou restringido a uma estrutura específica oral ou dentes, por aparelhos funcionais associados a forças extra orais é de fundamental importância. Esta ferramenta numérica permite, a partir do conhecimento da geometria 3D, inferir propriedades mecânicas dos tecidos e condições de apoio e carregamento, através da análise da distribuição de tensões mecânicas nas estruturas biológicas. 2) A importância do procedimento de modelação na precisão dos resultados experimentais, indicando a influência do tipo e número de elementos, nós e graus de liberdade usados no modelo deve ser investigada. 3) A pertinência de acompanhar estes estudos com ensaios clínicos e estudos in-vitro de validação, permitirá obter informação importante para otimizar o efeito dos aparelhos funcionais.

http://doi.org/10.24873/j.rpemd.2018.11.410

\section{\#SPODF-15 Alterações oro-faciais relevantes na síndrome de Kabuki para efeitos de tratamento ortodôntico}

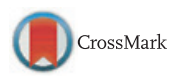

Sofia Mira De Almeida; Inês Correia Farinha

Introdução: A síndrome de Kabuki foi descrita por Niikawa e Kuroki, de forma independente, em 1981. A etiologia ainda é incerta mas, segundo estudos recentes, estima-se que a mutação associada ao gene MLL2 com transmissão autossómica dominante seja a principal causa. Entre as inúmeras alterações fenotípicas apresentadas nos doentes, as manifestações clínicas que constituem a Pêntade de Niikawa são as anomalias esqueléticas, alterações dermatoglíficas, debilidade intelectual leve a moderada, atraso no crescimento pré ou pós-natal e várias anomalias estruturais, algumas presentes na cavidade oral. Esta revisão narrativa pretende ressaltar as características fenotípicas, nomeadamente as alterações intraorais associadas à síndrome de forma a realizar um correto diagnóstico e seguimento clínico multidisciplinar.

Métodos: Pesquisa em artigos na base Pubmed e no livro "Diagnóstico e Tratamento em Ortodontia (2016, Elsevier, Espanha), através das palavras chave: "Síndrome de Kabuki", "Manifestações orais na Síndrome de Kabuki", "anomalias dentárias", "Fácies típica”, "Orthodontic treatment with Kabuki Syndrome”, publicados entre 2010 a 2016.

Resultados: Segundo a literatura, o paciente com esta síndrome apresenta fenda lábio-palatina (25\%), palato alto e estreito (88\%) e anomalias dentárias e de oclusão (63\%), onde se incluem os diastemas, agenesias do incisivo lateral superior, inferior ou do terceiro molar, mordida cruzada posterior, mordida cruzada anterior, mordida aberta anterior, sobremordida e o desvio da linha média dentária.

Conclusões: Esta síndrome é uma malformação que carece de tratamento multidisciplinar. Assim, torna-se vital que os médicos dentistas reconheçam as manifestações orais mais comuns, proporcionando um tratamento precoce e maximizando o bem-estar, autoestima e integração dos indivíduos portadores desta síndrome na sociedade.

Implicações clínicas: A caracterização fenotípica das manifestações orais e craniofaciais da síndrome pelos médicos dentistas tem um papel importante na divulgação da mesma permitindo o correto diagnóstico que ainda é baseado na ob- servação clínica. Devido ao défice cognitivo dos portadores desta síndrome, a dificuldade em realizar uma higiene oral adequada é uma realidade, pelo que o benefício do tratamento ortodôntico deve ser ponderado.

http://doi.org/10.24873/j.rpemd.2018.11.411

\#SPODF-16 Avaliação da Cinemática do Movimento Mandibular - Revisão Bibliográfica

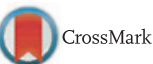

Paulo Fernandes Retto; Inês Anselmo Assunção; Hélder Nunes Costa; François Durant Pereira; Pedro Mariano Pereira

Instituto Universitário Egas Moniz

Introdução: A avaliação por axiografia da cinemática mandibular, na perceção do estado fisiopatológico da articulação temporomandibular e no registo dos determinantes anteriores e posteriores do movimento mandibular, esta generalizado na reabilitação oclusal. O objetivo desta revisão bibliográfica é esclarecer a importância deste exame na ortodontia, assim como identificar e caracterizar os diferentes achados pertinentes para o diagnóstico e terapêutica ortodôntica.

Métodos: Foi elaborada uma pesquisa bibliográfica nos motores de busca PubMed, B-on, Scielo e Science Direct e acervo bibliográfico do IUEM. Utilizaram-se na pesquisa as palavras-chave "axiography", "Condilography" e "mandibular kinematics”. Foram selecionadas publicações nas línguas inglesa, portuguesa e espanhola, e incluídos artigos e livros publicados entre 2000 e 2017.

Resultados: Da revisão bibliográfica realizada é possível verificar que a axiografia é um meio de diagnóstico que permite avaliar o movimento condilar quanto à sua quantidade, qualidade, característica, simetria e fenómenos de velocidade. Desta forma, a axiografia digital pode ser definida como um registo bilateral simultâneo cronometrado do movimento dos eixos de ambas as ATMs. O movimento é registado ao nível do eixo das ATMs, e o sistema de referência cartesiano montado permite avaliar o movimento quer dos côndilos, quer de qualquer peça dentária.

Conclusões: A avaliação da cinemática mandibular por axiografia revela-se ser um meio de diagnóstico com aplicabilidade diversa na área da ortodontia, em particular no diagnóstico em casos que apresentam disfunção articular e em casos interdisciplinares que exijam extensa reabilitação protética. Poderá igualmente ser uma mais valia no diagnóstico, monotorização e avaliação pós tratamento de casos em a terapêutica recorre a uma significativa alteração da posição mandibular.

Implicações Clínicas: O ortodontista deve avaliar cada caso e decidir quais os exames complementares de diagnóstico que poderão estar indicados. Para isso, tem de estar treinado para detetar anomalias à cinemática mandibular e para realizar o registo das mesmas, associando-os a uma adequada triagem e a outros exames complementares que se julguem pertinentes, permitindo assim um diagnóstico mais preciso da função articular e, consequentemente uma terapêutica mais adequada.

http://doi.org/10.24873/j.rpemd.2018.11.412 